\title{
An Appraisal of Entrepreneurial Skills of Construction Professionals to the Development of the Service Sector in Nigeria
}

\section{Ikupolati $\mathrm{AO}^{1 *}$, Adeyeye $\mathrm{MM}^{1}$, Oni EO ${ }^{1}$, Medubi $\mathbf{R}^{2}$ and Obafunmi $\mathrm{MO}^{3}$}

${ }^{1}$ Department of Entrepreneurship and Business Studies, School of Entrepreneurship and Management Technology, Federal University of Technology, Minna, Niger State, Nigeria

${ }^{2}$ Department of Architecture, School of Environmental Design, Kaduna Polytechnic, Nigeria

${ }^{3}$ Department of Food Technology, College of Science and Technology, Kaduna Polytechnic, Nigeria

\begin{abstract}
Construction industry is one of the important service sectors in Small and Medium Enterprises (SME). Construction industries are not "footloose" hence all progress that is made in improving the sustainability and performance of the construction industry the region and countries they operate in. The aim of this study is to investigate the entrepreneurial skills of construction professionals in the built environment of the development of the service sector in Nigeria. This was achieved by establishing innovativeness of construction professionals, determining willingness take risk by construction professionals and the roles of human resource management of construction professionals actually contribute to the development of the service sector in Nigeria. In this study construction professionals were restricted to only those in the built environment, consist of Architects, Builders, Estate valuers, Land Surveyors, Quantity Surveyors and Town Planners. The questionnaire was designed based on open-ended format of the item used. A total of 304 questionnaires were sent out to registered professionals in the built environment in Abuja and Lagos towns were construction of the built environment is visible. 204 questionnaires representing $67 \%$ of the sample were returned and deemed useable. The data were analyzed using percentage, graph and linear regression for descriptive and inferential analyses, respectively. Study established that majority (83.8\%) of the respondents agreed that entrepreneurial skills of construction professionals was statistically in explaining the development of the service sector in Nigeria. The study concluded that entrepreneurial skills of construction professionals contribute to the development of the service sector in Nigeria. The study recommends capacity building as this is paramount to development of the service sector in Nigeria through training, workshop etc.
\end{abstract}

Keywords: Construction industry; Construction professionals; Gross domestic product; Service sector and total employment

\section{Introduction}

The new century has brought with it several changes such advancement in technology and innovation to the construction industry and hence, challenges to the construction industry and the professionals who operate within it. In addition, there are also the construction industry specific problems of fragmentation and merging or blurring of professional services boundaries. According to Khairuddin [1], the construction industry is a fragmental industry which comprising large and small firms, including developing firms, consultancy service firms, construction firms and manufacturing firms. The industry comprises overlapping markets in terms of size, geographic location type and project complexity. The construction industry in developing countries such as Malawi employs 5-10\% of the direct workforce, in addition to employment in the various industries, which have linkages with construction, Khairuddin [1].

The construction industry is one of the important service sectors that Small and Medium Enterprise (SME) are involved in Construction industries are not "footloose", hence all progress that is made in improving the sustainability and performance of the construction industry, benefits the regions and countries they operate in, while at the same time, knowledge and experience can be built up internationally to strengthen the competitive position of the industry.

As of 2009, the construction sector in Netherlands consisted of almost 110,000 companies with a growth rate of $40 \%$. The sector contributes 7\% of the Gross Domestic Product (GDP) and 7\% of total employment thus assuming a position of considerable importance to the Dutch economy. The same sector in Nigeria contributes about $11 \%$ of GDP and provides $4 \%$ of total employment Central Bank of Nigeria [2].
Building and construction enterprises contribute largely to the economic growth of any nation and as such places huge demands on the sector to deliver the desired value for money. Small and Medium construction enterprises play an important role particularly in terms of employment creation and value orientation, thus the need for efficiency within the sector cannot be overemphasized Ofori [3]. The objective of this study is to investigate the entrepreneurial skills of construction professionals relating to the development of the service sector in Nigeria.

\section{Statement of the problem}

The contribution of construction projects to sustainable economic growth and development of a nation is very significant. Apart from the fact that they are major contributors to the Gross Domestic Product (GDP) and employment, they constitute the basic infrastructure needed to accommodate the inputs of all other sector of the economy Ogunsemi and Jagboro [4]. Oladapo [5] opines that these are professionals traditionally responsible for production and management of project information and documentation.

*Corresponding author: Ikupolati AO, Department of Entrepreneurship and Business Studies, School of Entrepreneurship and Management Technology, Federal University of Technology, Minna, Niger State, Nigeria, E-mail: alexikupolati@yahoo.com

Recieved April 17, 2017; Accepted June 16, 2017; Published July 23, 2017

Citation: Ikupolati AO, Adeyeye MM, Oni EO, Medubi R, Obafunmi MO (2017) An Appraisal of Entrepreneurial Skills of Construction Professionals to the Development of the Service Sector in Nigeria. J Entrepren Organiz Manag 6: 212. doi: 10.4172/2169-026X.1000212

Copyright: @ 2017 Ikupolati AO, et al. This is an open-access article distributed under the terms of the Creative Commons Attribution License, which permits unrestricted use, distribution, and reproduction in any medium, provided the original author and source are credited. 
Citation: Ikupolati AO, Adeyeye MM, Oni EO, Medubi R, Obafunmi MO (2017) An Appraisal of Entrepreneurial Skills of Construction Professionals to the Development of the Service Sector in Nigeria. J Entrepren Organiz Manag 6: 212. doi: 10.4172/2169-026X.1000212

Page 2 of 6

The Irish construction industry has undergone monumental change over the last decade from the peak in 2006, when construction accounted for almost 25\% of Gross Domestic Product (GDP) and 13\% of total employment, to current levels of $7 \%$ and $6 \%$ respectively in 2012. This shows a decline in the growth of the industry and therefore a need to resurrect it. In Malaysia, the construction sector represents nearly $3.5 \%$ of the country's Gross Domestic Product (GDP) and provides employment for about $10 \%$ of the total labour force. An increase in the growth of the construction sector implies that the total labour force through this would increase and thus boost the GDP of the country OECD [6]. In Nigeria, the management of construction firms has been involved in merger, service diversification and forming consortium with allied and non-allied professions with the aim of sustaining competitiveness and improving performance.

Despite these performances strives, there are persistent calls by experts and researchers Kawu [7] for improved performance of the construction firms signaling that their performance is unsatisfactory. It is against this background that this study seeks to investigate the entrepreneurial skills of construction professionals to the development of the service sector in Nigeria.

\section{Objectives}

\section{Main objective}

To investigate the entrepreneurial skills of construction professionals to the development of the service sector in Nigeria.

Specific objectives

1. To establish whether innovativeness of the construction professionals influence the development of the service sector in Nigeria.

2.To determine if willingness to take risk by construction professional influence the development of the service sector in Nigeria.

3.To investigate the role of human resource management of construction professionals in the development of the service sector in Nigeria.

\section{Research hypothesis}

1. Ho: There is no significant relationship between innovativeness of the construction professionals and the development of the service sector in Nigeria.

2. Ho: There is no significant relationship between willingness to take risk by construction professionals and the development of the service sector in Nigeria.

3. Ho: There is no significant relationship between the role of human resource management of the construction professionals and the development of the service sector in Nigeria.

\section{Literature Review}

\section{Entrepreneurial skills of construction professionals}

There are some literature and a body of practice in both development and fields such as venture capital that claims to identify which personal skills of individual entrepreneurs might lead to firm development and success. This discussion focuses on skills that can be objectively determined and for which there is empirical evidence. The skills are innovativeness, willingness to take risk and human resource management of the construction professionals.

\section{Innovativeness}

Innovativeness within the construction firms relies on the management of knowledge acquisition and the capturing of projects based on learning for future use. Innovation was specifically defined to include both technologically and organizational improvement. Incremental as well as radical or breakthrough changes were both regarded as innovations.

Construction professionals generally, saw the construction industry as the main driver of innovation. Majority of construction professionals regarded innovation as generally profitable. Increased training and information programs, best practice demonstrations and the hiring of skilled people as ways of encouraging innovation. They also saw a need for more open construction attitudes.

Awareness of this multi-dimensional nature of innovation is unevenly spread through the different areas of the industry and different points along the process. This explains some of the variations in favored strategies to encourage innovation.

\section{Willingness to take risk}

In a complex and dynamic industrial environment the role played by the various professions is likely to fluctuate and change. New technologies make some traditional roles obsolete and others may be greatly altered in scope and responsibilities.

Computer programs which aim to deliver automatic quantities and pricing for 3D computer drawings are in the process of development in several places, while the application problems are by no means small, it is possible that future programs will be available that will take over these parts of construction works that are repetitive and routine.

The professions will need to concentrate on their value adding and organizational skills if it is to continue to prosper. Due to proper recognition of the role played by the professionals in the construction industry, the roles are needed, if the benefits of their expertise are not to be lost. In this way the construction professionals can become more integrated into the currently developing collaborative construction industry structure.

\section{Human resource management}

Human resource management (HRM) involves practices that ensure that employees' collective knowledge, skills and abilities contributes to business outcomes. The traditional conceptualization of HRM focused on managing, measuring and controlling organizations workforce. Tactical or technical HRM includes selection, testing, training, performance measurement and administration of benefits.

The human resource benefit that is based on commitment is focusing on the psychological links between organizational and employee's goals. It is associated with higher involvement in managerial decision, participation, providing training and rewards. A human resource system that is based on control focuses on directly monitoring and rewarding employee behaviour or the specific outcomes of that behavior Arthur [8]. Human resources are considered as the most valuable asset in an organization, they make a difference only for a few organizations.

\section{Development theory}

Kilhstrom and Laffarl [9] model incorporate risk into the analysis of enterprise growth. Kilhstrom and Laffarl [9] argue that the key attribute of the entrepreneur is a taste of risk. They argue that 
Citation: Ikupolati AO, Adeyeye MM, Oni EO, Medubi R, Obafunmi MO (2017) An Appraisal of Entrepreneurial Skills of Construction Professionals to the Development of the Service Sector in Nigeria. J Entrepren Organiz Manag 6: 212. doi: 10.4172/2169-026X.1000212

Page 3 of 6

entrepreneurs normally assume more risk than employees. In their theory, they contend that risk lovers became entrepreneurs while risk averters become employees.

\section{Research Framework}

The primary variable of interest of the study is the dependent variable of development which is measured by the annual turnover of firms and the number of employees. The independent variables that may influence the dependent variable are innovativeness, willingness to take risk and the human resource management of the construction professionals. The relationships between the dependent and independent variables are shown in Figure 1.

\section{Research method}

In this research, construction professionals were restricted to only those in the built environment. They are Architects, Builders, Estate Valuers, Land Surveyors, Quantity Surveyors and Town Planners. For the purpose of data collection, a survey questionnaire was conducted among registered professionals with their respective professional bodies. The questionnaire was designed based on open-ended format of the items used. To test the content validity, the questionnaire was initially distributed to expert panels of 8, comprising Architect, builder, Estate Valuer, Land Surveyor, Quantity Surveyor, Town Planner, Statistician and Academia knowledgeable in the area of firm development. This was followed by a pilot survey to get an initial feedback on the content of the questionnaire.

During the pilot survey, 15 respondents cutting across all the professionals in the built environment were collected and the questionnaire was then amended according to their comments before the actual feedback began. In the main survey, a total number of 304 questionnaires were sent out to registered professionals in the built environment in Abuja and Lagos towns were constructions of the built environment are visible with high level of operations. After three months period, $204(67 \%)$ of the questionnaires were returned and deemed useable. The data were analyzed using both descriptive and inferential statistics to establish the findings.

\section{Data Analysis}

Objective 1: To establish whether innovativeness of the construction professionals influence the development of the service sector in Nigeria.

\section{Descriptive analysis}

The study revealed that $100 \%$ of the respondents agreed that there are policies measure at stimulating innovative skills of the professionals. This finding relate to Schumpeterian theory on innovation. Schumpeters [10] theory of innovative profits emphasized the role of entrepreneurship and the seeking out of opportunities for



Figure 1: Showing the conceptual framework. annual value and generating activities which would expand the circular flow of income through risk taking.

Inferential analysis: Development was regressed on innovativeness. The relationships among the variables are depicted below:

$$
\begin{aligned}
& \mathrm{Y}=\mathrm{B}_{\mathrm{o}}+\mathrm{B}_{1} \mathrm{X}_{1} \text {, where } \\
& \mathrm{Y}=\text { Development of the service sector in Nigeria } \\
& \mathrm{B}_{\mathrm{o}}=\text { Constant (co-efficient of intercept) } \\
& \mathrm{X}_{1}=\text { Innovativeness } \\
& \mathrm{B}_{1}=\text { Regression Coefficient }
\end{aligned}
$$

Linear regression was used to measure the linear relationship between the independent and dependent variables.

Table 1 shows that the correlation coefficient (R) between innovativeness and the development of service sector in Nigeria is 0.601 implying a strong linear relationship between innovativeness and development of service sector in Nigeria. The coefficient of $\mathrm{R}^{2}$ adjusted is 0.201 indicating that $20.1 \%$ of the variation in the development of the service sector in Nigeria was explained by innovativeness.

a. Predictor (constant) innovativeness.

Table 2 shows an ANOVA test performed on innovativeness. It has p-value equal to 0.004 which is lower than $\alpha(0.05)$ therefore conclude that the model is significant and therefore fit for use.

a. Department variable: Development of service sector in Nigeria.

b. Predictor (constant) Innovativeness.

Table 3 shows regression coefficient $B_{1}$ is standardized because it has a bound, thus coefficient interval can be formed. The table shows that linear relationship between innovativeness and development of service sector in Nigeria is $\mathrm{Y}=12.250+6.062 \mathrm{x}_{1}$ where $\mathrm{Y}$ is the development of the service sector in Nigeria and $\mathrm{X}_{1}$ is Innovativeness. The P-value of the slope of model 0.004 is less than a (0.005) therefore Ho is rejected and it is concluded that innovativeness has a significant role in the development of the service sector in Nigeria.

a. Dependent variable: Development of the service sector in Nigeria.

Objective 2: To determine if willingness to take risk by construction professionals influence the development of the service sector in Nigeria.

\begin{tabular}{|c|c|c|c|c|}
\hline Model & R & R2 & Adjusted R2 & $\begin{array}{c}\text { Std error of } \\
\text { estimate }\end{array}$ \\
\hline 1 & 0.601 & 0.361 & 0.201 & 2.31816 \\
\hline \multicolumn{4}{|c|}{ Table 1: Model summary. } \\
\hline \multicolumn{4}{|c|}{} \\
\hline
\end{tabular}

\begin{tabular}{|c|c|c|c|c|c|}
\hline Model & $\begin{array}{c}\text { Sum of } \\
\text { square }\end{array}$ & df & $\begin{array}{c}\text { Mean } \\
\text { square }\end{array}$ & F & Sig \\
\hline Regression & 19.021 & 1 & 19.021 & 10.45 & 0.004 \\
\hline Residual & 7.313 & 4 & 1.828 & & \\
\hline Total & 26.334 & 5 & & & \\
\hline \multicolumn{5}{|c|}{ Table 2: ANOVA. }
\end{tabular}

\begin{tabular}{|c|c|c|c|c|c|}
\hline Model & $\begin{array}{c}\text { Unstandardized } \\
\text { B }\end{array}$ & std error & $\begin{array}{c}\text { Standardized } \\
\text { Beta }\end{array}$ & $\mathbf{t}$ & Sig \\
\hline Constant & 12.25 & 10.288 & & 1.254 & 0.001 \\
\hline Innovativeness & 6.062 & 10.35 & 0.601 & 1.503 & 0.004 \\
\hline
\end{tabular}

Table 3: 
Citation: Ikupolati AO, Adeyeye MM, Oni EO, Medubi R, Obafunmi MO (2017) An Appraisal of Entrepreneurial Skills of Construction Professionals to the Development of the Service Sector in Nigeria. J Entrepren Organiz Manag 6: 212. doi: 10.4172/2169-026X.1000212

Page 4 of 6

\section{Descriptive analysis}

The study revealed that $75.7 \%$ of the respondents agreed that there are policies measure aimed at encouraging risk taking by the construction professionals.

Figure 2 shows the risk taking ability of the professionals from 2009-2013. Year 2013 recorded the highest percentage of 85.5\%, 2012$80 \%, 2010$ and $2009-65 \%$ and $2011-55 \%$ as illustrated in Figure 2. This gives an average for the period studied as $68.75 \%$. This shows that the professionals generally took a high-risk ability in years 2013 and 2012 which has tremendously influenced the development of the service sector in Nigeria.

\section{Inferential analysis}

Development was regressed on willingness to take risk. The relationships among the variables are depicted below

$\mathrm{Y}=\mathrm{Bo}+\mathrm{B}_{2} \mathrm{X}_{2}$, where

$\mathrm{Y}=$ Development of service sector in Nigeria

$\mathrm{Bo}=$ Constant (coefficient of intercept)

$\mathrm{X}_{2}=$ Willingness to take risk

$\mathrm{B}_{2}=$ Regression coefficient

Linear regression was used to measure the linear relationship between the independent and dependent variables.

Table 4 shows that the correlation coefficient (R) between willingness to take risk and the development of service sector in Nigeria is 0.760 implying a strong linear relationship between willingness to take risk and the development of service sector in Nigeria. The coefficient of $\mathrm{R}^{2}$ adjusted is 0.231 indicating that $23.1 \%$ of the variation in the development of service sector in Nigeria was explained by willingness to take risk.

Table 5 shows an ANOVA test performed on willingness to take risk. It has a P-value equal to 0.000 which is lower than $\alpha(0.05)$; therefore we concluded that the model is significant and therefore fit for use.

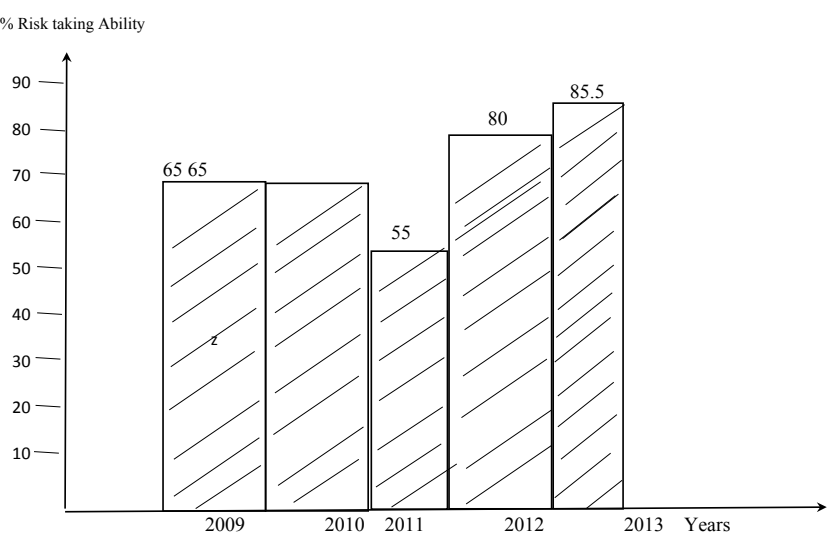

Figure 2:

\begin{tabular}{|c|c|c|c|c|}
\hline Model & $\mathbf{R}$ & $\mathbf{R 2}$ & Adjusted R2 & $\begin{array}{c}\text { Std error of } \\
\text { estimate }\end{array}$ \\
\hline 1 & 0.76 & 0.578 & 0.231 & 2.56535 \\
\hline
\end{tabular}

Predictor (constant) willingness to take risk.

Table 4: Model summary.

\begin{tabular}{|c|c|c|c|c|c|}
\hline Model & $\begin{array}{c}\text { Sum of } \\
\text { square }\end{array}$ & df & $\begin{array}{c}\text { Mean } \\
\text { square }\end{array}$ & F & Sig \\
\hline Regression & 8.304 & 1 & 8.304 & 6.606 & 0 \\
\hline Residual & 5.029 & 4 & 1.257 & & \\
\hline Total & 13.333 & 5 & & & \\
\hline
\end{tabular}

Table 5: ANOVA.

\begin{tabular}{|c|c|c|c|c|c|}
\hline Model & $\begin{array}{c}\text { Unstandardized } \\
\text { B }\end{array}$ & std error & Std & $\mathbf{t}$ & Sig \\
beta & & 1.009 & 0.003 \\
\hline $\begin{array}{c}\text { Constant } \\
\text { willingness }\end{array}$ & 3.529 & 0.324 & & 4.249 & 0 \\
\hline To take risk & 0.324 & 0.298 & 1.24 & & \\
\hline
\end{tabular}

a. Dependent Variable: Development of Service Sector in Nigeria.

b. Predictor (constant) Willingness to Take Risk.

Table 6 shows Regression Coefficient. $\mathrm{B}_{2}$ is standardized because it has a bound thus confidence interval can be formed. The table shows that linear relationship between willingness to take risk and development of service sector in Nigeria is $\mathrm{Y}=3.529+0.324 \mathrm{X}_{2}$ where $\mathrm{Y}$ is the development of the service sector in Nigeria and $\mathrm{X}_{2}$ is willingness to take risk. The p-value of the slope of the model 0.000 is less than $a$ $(0.05)$ therefore Ho is rejected and it is concluded that willingness to take risk has a significant role in the development of the service sector in Nigeria.

a. Dependent variable: Development of Service Sector in Nigeria.

Objective 3. To investigate the role of human resource management of construction professionals in the development of the service sector in Nigeria.

\section{Descriptive analysis}

The study revealed that $75.7 \%$ of the respondents agreed that they have policy on human resource management in their firms. The finding relates to performance based theory which is the dominant human resource practice that firms use to evaluate and reward employees efforts Collins and Clark [11]. Evidently, performance based compensation has a positive effect upon employees and organizational performance.

Inferential analysis: Development was regressed on human resource management. The relationship among the variable are depicted below:

$\mathrm{Y}=\mathrm{Bo}+\mathrm{B}_{3} \mathrm{X}_{3}$, where

$\mathrm{Y}=$ Development of the service sector in Nigeria

$\mathrm{Bo}=$ Constant (coefficient of intercept)

$\mathrm{X}_{3}=$ Human resource management

$\mathrm{B}_{3}=$ Regression coefficient

Linear regression was used to measure the linear relationship between the independent and dependent variables.

Table 7 shows the correlation coefficient (R) between the human resource management and the development of the service sector in Nigeria is 0.605 implying a strong linear relationship between human resource management and the development of the service sector in Nigeria. The coefficient of $\mathrm{R}^{2}$ adjusted is 0.201 implying that $20.1 \%$ of 
Citation: Ikupolati AO, Adeyeye MM, Oni EO, Medubi R, Obafunmi MO (2017) An Appraisal of Entrepreneurial Skills of Construction Professionals to the Development of the Service Sector in Nigeria. J Entrepren Organiz Manag 6: 212. doi: 10.4172/2169-026X.1000212

Page 5 of 6

the variation to the development of the service sector in Nigeria was explained by human resources management.

\section{a. Predictor (constant) Human Resource Management.}

Table 8 shows an ANOVA test performed on human resource management. It has a p-value equal to 0.001 which is lower than a (0.05), therefore conclude that the model is significant and therefore fit for use.

a. Dependent variable: Development of Service Sector in Nigeria.

b. Predictor (constant) Human Resource Management.

Table 9 shows regression coefficient. $\mathrm{B}_{3}$ is standardized because it has a bound thus confidence interval can be formed. The table shows that linear relationship between human resources management and the development of the service sector in Nigeria is $Y=12.250+6.062$ $\mathrm{X}_{3}$ where $\mathrm{Y}=$ the development of the service sector in Nigeria and $\mathrm{X}_{3}$ human resource management. The P-value of the slope of the model 0.001 is less than $\alpha(0.05)$ therefore $\mathrm{H}_{\mathrm{o}}$ is rejected and it is concluded that human resource management has a significant role in the development of the service sector in Nigeria.

a. Dependent variable: Development of the service sector in Nigeria.

\section{Discussion}

The study established that majority $(83.8 \%)$ of the respondents agreed that entrepreneurial skills of construction professionals influenced the development of service sector in Nigeria. Entrepreneurial skills of construction professionals were statistically significant in explaining the development of the service sector in Nigeria. A majority of $83.8 \%$ of the respondents pointed out that there were policies aimed at stimulating innovative skills of professionals, policy measures aimed at encouraging risk taking and human resource management in their firms.

For innovativeness correlation coefficient $(\mathrm{R})$ is 0.601 implying a strong linear relationship between innovativeness and development of service sector in Nigeria. $20.1 \%$ of the variation in the development of the service sector in Nigeria was explained by innovativeness. The Linear relationship between the two variables is $\mathrm{Y}=12.250+0.062 \mathrm{X}$. For willingness to take risk the correlation coefficient $(\mathrm{R})$ is 0.760 implying

\begin{tabular}{|c|c|c|c|c|}
\hline Model & R & R2 & R2 Adjusted & $\begin{array}{c}\text { Std error for } \\
\text { estimate }\end{array}$ \\
\hline 1 & 0.65 & 0.366 & 0.201 & 2.31816 \\
\hline \multicolumn{4}{|c|}{ Table 7: Model summary. } \\
\hline \multicolumn{4}{|c|}{} \\
\hline
\end{tabular}

\begin{tabular}{|c|c|c|c|c|c|}
\hline Model & $\begin{array}{c}\text { Sum of } \\
\text { square }\end{array}$ & df & $\begin{array}{c}\text { Mean } \\
\text { square }\end{array}$ & F & Sig \\
\hline Regression & 19.021 & 1 & 19.021 & 10.405 & 0.001 \\
\hline Residual & 7.313 & 4 & 1.828 & & \\
\hline Total & 26.334 & 5 & & & \\
\hline \multicolumn{7}{r}{} \\
\hline
\end{tabular}

Table 8: ANOVA

\begin{tabular}{|c|c|c|c|c|c|}
\hline Model & $\begin{array}{c}\text { Unstandardized } \\
\text { B }\end{array}$ & std error & $\begin{array}{c}\text { standardized } \\
\text { beta }\end{array}$ & T & Sig \\
\hline Constant & 12.25 & 10.288 & & 11.254 & 0 \\
\hline $\begin{array}{c}\text { Human } \\
\text { resource } \\
\text { management }\end{array}$ & 6.062 & 10.35 & 0.601 & 11.503 & 0.001 \\
\hline
\end{tabular}

Table 9: a strong linear relationship between willingness to take risk and development of the service sector in Nigeria $23.1 \%$ of the variation in the development of service sector in Nigeria was explained by willingness to take risk. The linear relationship between the two variables is $\mathrm{Y}=3.529+0.324 \mathrm{X}_{2}$. For the role of human resource management the correlation coefficient $(\mathrm{R})$ is 0.605 implying a strong linear relationship between human resource management and the development of the service sector $20.1 \%$ of the variation to the development of the service sector in Nigeria was explained by human resource management. The linear relationship between the two variables is $\mathrm{Y}=12.250+6.062 \mathrm{X}_{1}$.

Innovativeness, risk taking and human resources management by the construction professionals will bring about diversion of human capital that will eventually lead to the development of service sector in Nigeria.

\section{Conclusions}

Innovativeness has enhanced the productive capacity and the development of the service sector as the employees are trained periodically to meet with current technologies and areas of diversification. Firms take indemnity insurance policy for every professional staff as a cover for any professional misconduct as this has enhanced the development of the service sector. Firms have attracted new businesses for itself as a result of calculated risk taking every year. Staff were encouraged to develop themselves by attending seminars, training and furthering their education. This has led to a high capacity building for staff of the firms.

For innovativeness $\mathrm{H}_{0}$ is rejected because $\mathrm{p}$-value (0.004) is less than $a(0.05)$ thus innovativeness has a significant role in the development of the service sector in Nigeria For Willingness to the risk Ho is rejected because p-value (0.000) is less than $\alpha(0.05)$ thus Willingness to take risk has a significant role in the development of the service sector in Nigeria. For Role of Human resource Management, Ho is rejected because p-value (0.001) is less than $\alpha(0.05)$ thus Human resource management has a significant role in the development of the service in Nigeria.

The researcher concluded that entrepreneurial skills of construction professionals contributed to the development of the service sector in Nigeria.

\section{Recommendations}

1. All professionals of the construction industry are encouraged to further their education, attend conferences and seminars where new ideas are shared among colleagues so as to brace up with time and currency of discoveries. Capacity building is paramount to development in the service sector in Nigeria.

2. Firms should take indemnity insurance policy for every professional staff as a cover for any professional misconduct that might occur in the process of executing their duties.

3. Construction professionals should be trained in new and current technology with new software in the various professions that will enhance the productivity capacity and development of the service sector in Nigeria.

\section{References}

1. Khairuddin AR (2002) Construction Procurement in Malaysia Process and Systems Constraints and Strategies. Kuala Lumpur: Ilum.

2. Central Bank of Nigeria (CBN) (2008) Annual Reports and Statement of Accounts of the Federal Republic of Nigeria for the year ended $31^{\text {st }}$ December, 2007. 
Citation: Ikupolati AO, Adeyeye MM, Oni EO, Medubi R, Obafunmi MO (2017) An Appraisal of Entrepreneurial Skills of Construction Professionals to the Development of the Service Sector in Nigeria. J Entrepren Organiz Manag 6: 212. doi: 10.4172/2169-026X.1000212

3. Ofori G (2001) Indication for measuring Construction Industry Development in Developing Countries. Building Research and Information 29: 40-50.

4. Ogunsemi DR, Jagboro GO (2006) Time Cost Model for Building Projects in Nigeria. Constructions Management and Economics 24: 253-258.

5. Oladapo AM (2000) Project Performance in a Changing Environment. AACE International Transactions. Int 09: 19.1-19.10.

6. OECD (2004) African Economic Outlook pp: 247-260.

7. Kawu AM (2011) State of Quantity Surveying Practice in Nigeria: Proceedings of the 2011 Quantity Surveying Assembly and collogium held at Shehu Musa Yar'adua Centre, Abuja, 28 ${ }^{\text {th }}$ and 29 ${ }^{\text {th }}$ September 2011.
8. Arthur JB (1994) "The Link between Business Strategy and Industrial Relations System and American Steel Maimills". Industrial and Labour Relations Review 45: 488-506.

9. KilHstrom R, Laffarl J (1979) Implication Labour contracts. Journal of Economic Theory 20: 231-259.

10. Schumpter JA (1934) The Theory of Economic Development Cambridge. Mars: Harvard.

11. Collins CJ, Clark KD (2003) Strategic Human Resources Practices, Top Management Commitment, Team Social Networks and Firm Performance: The role of Human Resources Practices in creating Organizational Competitive Advantage. The Academy of Management Journal 46: 740-751. 